\title{
Islamic Tradition: Islamic Mass Organization Responses To Shia's Eid Ghadir Tradition In Jakarta Bandung
}

\author{
Agus Masrukhin ${ }^{1}$, Reiza D Dienaputra ${ }^{2}$, Dadang Suganda ${ }^{3}$, Titin Nurhayati ma'mun ${ }^{4}$ \\ \{1 ${ }^{1}$ gus @ binus.ac.id , ${ }^{2}$ reiza.dienaputra@unpad.ac.id, ${ }^{3}$ dadangsuganda60@gmail.com, \\ ${ }^{4}$ titin.mamun@unpad.ac.id\} \\ ${ }^{1,2,3,4}$ CBDC , Sistem informasi, Bina Nusantara University Jakarta Indonesia 11480
}

\begin{abstract}
Shia and Sunnis have long been in Indonesia, but until now, the relationship between Sunni and Shias organizations in Indonesia remains less harmonious. The purpose of this study is to analyze the construction of Eid al Ghadir tradition especially in Jakarta and Bandung, and to explain the behavioral response of Islamic organizations to Eid al-Ghadir tradition in Jakarta and Bandung. Starting from the response theory and challenge of Toyn Bee [1], the Eid al-Ghadir tradition is the response of the case of Ali quoting Prophet Muhammad Saw. As well as risking the concept of Imamah. Rejection and acceptance of Eid ghadir tradition due to various factors one of them negative stigma against shia.
\end{abstract}

Keywords: Eid Ghadir, Response, Shia, Sunni

\section{Introduction}

\subsection{Background}

Every 18 Dzulhijah is a day of Idul ghadir celebration conducted by Shiites around the world, especially Iran State. According Akmal head of research Islamic Culture Center embassy of the Islamic Republic of Iran in Jakarta. That al-Ghadir is a glorious event and a big day of Islam all Muslims in the world especially for the Shia, it is no wonder that day became a national holiday for the people of Iran.[2]The event is always perpetuated by the Shia every year. This is a very important event related to Imamat, while Imamat is a pillar of faith for the Shiites. In fact this should also be believed not only the Shia but by all Muslims. Zulkifli in his book The Struggle of shi'is in Indonesia, states: Imamate is the fundamental tenet that distinguishes the Shi'is from the Sunni and therefore, it is an element of Shi'ism. [3] According to Shia the Imam is the infallible person chosen by Allah, for the Shia the position of the Imam has been determined, it is no wonder they believe the twelve Imams, among them Imam Ali, Imam Hasan, Imam Hussein, Imam Zainal abidin, Imam Ja'far sidik, Imam Mahdi and other Imams. Ris'an Rusli has a conclusion in his Intizar Journal that, Imamah is the most important matter in the Shi'a, for which they are also divided into many sects. The Imami Shi'ah Itsna 'Asyariyah assumes that the priest's office is in the hands of the twelve Imams starting from Ali ibn Abi Talib and the last twelfth Imam Muhammad bin Hasan is dubbed as al-Mahdy. The Imam is very principled after the death of Prophet Muhammad, as a spiritual guide and the harmony of human life. The statement was delivered by Zulkfli in his book the 
struggle of shi'is in Indonesia p. 97 Rejection of Idul ghadir activities in Indonesia is also still occurring, either in pyroly or mass and forntal. This internal conflict of Muslims is heartbreaking, it has had a major impact on the progress and well-being of the Ummah, as seen how devastated it is for some countries on Middle-earth such as Syria and Iraq. Indonesia as a predominantly Muslim country. This becomes the homework and biggest challenge for all Indonesian people. In this context, the real thing that makes the point is the mutual claim of each group's frontal truth towards the other group. Abdurrahman as a minority advocate conveys, the Shia is the fifth school after the four schools (Historia, No.6, 2012). [4]

\subsection{ResearchObjectives}

The main problem that will be analyzed in this research is how the construction of Idul Ghadir tradition in Indonesia, especially Jakarta bandung? why did the Shi'a celebrate the Eid al-Ghadir tradition and how would the Sunni and Shia Muslim community organize their response to the tradition of the Eid Ghadir celebration?

\section{TheoreticalFramework}

Departing from Toynbee's response theory [5] the response due to the challenge, the response can be positive or negative. The response of the Shia in Benny Afwadzi, to Hermeneia: Journal of Interdisciplinary Islamic Studies, Vol. 14, No. 1, January - June 2014, contends the Ghadīr Khum Hadith contained in Sunni and Shia collections and other forms of interpretation. The hadith Ghadīr Khum (kuntu maulāhu fa aliyyun maulāhu) is one of the arguments of the Shi'ites that Ali bin Abi Talib was the leader after Prophet Muhammad died. This hadith is contained in Sunni and Shia collections and is regarded as a sahih Hadith even mutawātir. The Shi'ah argue for the truth of the Eid al-Ghadir traditionThis is different from the dissertation data: The Struggle of the Shi'is in Indonesia Book, the author of Zulkifli Publisher: ANU Press, published in 2013. The book of scientific work entitled The Struggle of the Shi'is in Indonesia has become very important to be primary information in this dissertation because it contains data on the response of Shia traditions and matters relating to the history and development of Shia in Indonesia. According to research conducted by the author of the book, the majority of Indonesian citizens reject the teachings of the Shia. Among the Islamic organizations that menolakanya are Persis, Al-Irsyad, NU and Muhammadiyah. If Persis and Al-Irsyad refused loudly until giving a fatwa that essentially opposed all the Shia teachings. Another case of NU and Muhammadiyah seems to be more patient and open, though not declaring heretics and infidels to Shiites but giving a fatwa to not follow the teachings of the Shia. [6] Thus can be drawn hepotesa there are several variables that need to be considered for the discussion are: Imamah concept, Ghadir khum tradition values, respect to ahlu bait and the response of Islam mass organizations of Shia and Sunni.

\section{ResearchMethodology}

This researc his a descriptive study using a qualitative approach. Categorizedin descriptiveresearchbecause theresearch was conducted in orderto determine anevent, namely the Tradition of Idul Ghadir: Islamic Mass Organization Responses To Shia' Ghadir Tradition 
In Indonesia.Thisisconsistentwithoneofthe goals of descriptive research, which is intended to carry out exploration and clarification of phenomena or socialreality by way of describing a number of variables related to the problem and the unit understudy. Describes descriptive research method with the following characteristics. First, focus on solving the problems that exist in the present, the actual problems. Second, data collected at first arranged, described,andthenanalyzed) [7]. This research using interpretative approach with responses analysis. [8 This analysis begins by describing the reality of the spiritual activities at the Tangerang Youth Prison. After data is collected, the data obtained is read, studied, and reviewed in depth. Next is to do data reduction that is considered important and useful, doing data interpretation and analyzed.

\section{Results Discussion}

\section{1 overview}

The Imamah concept, Ghadir Tradition values khum, respect to ahlu bait and the response of the mass of Shia and Sunni Islam. Islam. Sunni Muslims do not acknowledge that the last sermon took place and did not celebrate the day, as they believed that, in Islam, the days considered to be celebrations were only Eid and Eid al-Adha. [9] [10] al Hadits said "Ali is the person appointed by Muhammad (to be Caliph). Shia narrated this hadith to support his beliefs, the scholars of Sunnah and their narrators hadith did not recognize this tradition. [1] Most of these hadiths are superstitious, or [2] Some of its prophets are questionable, or [3] The correct interpretations are in their opinion different from those interpreted by Shi'ites. "[11] the legal basis of the following hadith:"Ali is my mawla in the sense that I am his mawla "[12]

\subsection{Idul Ghadir Ethics[13]}

The tradition of Eid ul-Ghadir is very meaningful for the Shia community, there are some Ethics in celebrating Eid al-Ghadir:

1. Good Charity, In the Shi'ah belief, the whole of the al-Ghadir festival is each a Good Charity, but in a general rule and as an introduction this adab-adab is contained in the narration: "Every good charity is equal to good deeds for eighty months. "(Iqbâl 'Amal, p.446) Therefore, the day of Al-Ghadir is to have roles such as the month of Ramadan and the night of Qadhar. From here, it can be mentioned that righteous deeds in these days and nights are always in an open state. At these times, it is appropriate for the human being to make the most of this time so that he can do Good Charity.

2. Encourage Worship, Imam Rida said, Al-Ghadir is the day when Allah will add sustenance to the worshipers on that day.'1 Definition of worship in general is all deed done with intention qurbah (closer) and will be the cause of his nearness to the Lord. Worship is the meaning of this may be shaped mubah actions. That is, if man in his daily deeds by intending taqarrub and reap the pleasure of Allah, then the whole act is counted as worship. Worship advised to be done on the day of Al-Ghadir includes all the kinds of worship we know in Islam. Doing the prayers, fasting, bathing, praying, praising and thanksgiving, pilgrimage, delivering shalawat and expressing barâ'at (enchantment) from enemies, each one of these blessed days. 
3. Fasting Fasting, Fasting is a form of worship as well as mandatory in the month of Ramadan, there is also a mustahab which is done every day of the year, in addition to the days of Iedul Fitri and Iedul Qurban. However, on certain days it is highly recommended to do so. The histories mention the high values of the fasts. One such fast is the fast of the day of Al-Ghadir. The Imams of the Most High do not only require them to fast today, but they also encourage their relatives and friends to follow them fasting.

4. Prayers, Likewise, most days and special circumstances, he does special prayers for the day and circumstances.

5. Pilgrimage, Pilgrimage is a source of springs that spewed water to the forgotten noble to remove his thirst and fill his soul with silence and purify his spirit from the heat of separation in the flow of qurb. Pilgrimage is a fruit of grace and reward given to the salik for their patience. The prayer of pilgrimage is an unreadable letter of a constant life and a vehicle of grace.

6. Celebrate, In contrast to the 'asuras' memorial celebrated with sorrow and grief, it is like banging on a limb. The Eid celebration of Ghadir is done with a joyful atmosphere such as cheering and reading the praises. This celebration It is praiseworthy for believers to be different today than their usual days - within normal limits and shar'i.

7. Praying, the day of Al-Ghadir is the best time and special circumstances for praying Imam Rida said, The Day of Ghadir is the day when prayer is accepted (mustajabah). (Iqbal Al-'Amal, p.454) For this reason, besides there are prayers quoted from the narrations on the ta'qib-ta'qib prayers of the mustahab and various events on this day, there are also prayers that are read separately. The main focus in the prayers of the day of Al-Ghadir is the pleasure of wilayat.

\subsection{Values Eid Ghadir}

Related to Idul Ghadir celebration based on Koentjaraningrat frame of mind (1990, pp186-187), then the form of Eid ul-Ghadir tradition can be expressed to have three forms, namely: first, the form of ideas, ideas, values, norms, rules and so on . Second, activities and actions pattern. Third, the form of objects of human works. This context will be described about Significant Values in the Eid al-ghadir tradition. [14]

First is the Idea in the Eid al-Ghadir tradition is a belief in the truth that Imam Ali is a substitute for the leader of the people according to the Hadith narrated by Imam Ahmad ibn Hanbali and other narrators and the Qur'an Surah Al-Maidah verse 67. The second is a form of activity, there is a ritual that is always celebrated by the Shias all over the world with various charities of Worship and manner, such as recitation and prayer. The third is the form of things in there are some related Idul ghadir among which the authors get is the manuscripts of the Prophet's speech in the wada pilgrimage and Ghadir khum incident, special prayer texts of Eid al-Ghadir celebrations, the scripts of the imam's advice will be fadhilah charity worship in the feast of Eid Ghadir khum.

\subsection{Islamic Mass Organization Responses}

So far, the response of religious organizations to Shiites in Indonesia is fairly normal and does not lead to extreme acts of violence. But the escalation to open conflict is not impossible for Indonesia. The majority of Muslims are Sunni, so are those influential individuals and institutions within the Shi'i community in Indonesia which have, through their small numbers, 
created opportunities through which to teach the madhhab. The Sunni Muslim majority.These responses to Shi'ism are a direct result of the nature of Islam in Indonesian society and the state. The majority Muslim population is Sunni, but within a group there are reformist and traditionalist factions with their several related organizations.[15]

\subsubsection{FUUI}

The first group, which actively responded to the rejection was conducted by the Islamic Society of FUUI. the name of the Islamic Scholars Forum (FUUI). This community-based organization in Bandung is a Sunni school. In addition to different theological aspects, at several meetings between these two key organizational figures this seems to imply personal conflict. The rejection of Shias is based on findings and discussions in KH-led recitation. Athian Ali Da'i. The results of the study were also presented on the occasion of da'wah and lectures by the officials and followers of FUUI in various regions. This method is very effective in spreading anti-Shia stance to the grassroots community. Moreover, many FUUI activists are ustaz and the organizers of taklim assemblies have closeness with the community. Fatwa Forum Ulama Ummat Indonesia (FUUI) No. 04 / Rabiuts Tsani / 1433 on Shi'ism: 1. The person / group that believes, teaches and spreads it in whole or part of Shi'ism above, who believes himself to be Shi'ite or not is heretical and misleading and is outside of Islam. 2. Muslims should limit the interaction, both personal and group with Shiite followers to avoid themselves and families from the influence of their heresy. [16]

\subsubsection{PERSIS}

Organization of Islamic societies Persis, Over the years, Persis has induced intense resistance to Shi'ism and Shi'is in Indonesia, using a variety of methods. Quite simply, Persis believes that Shi'ism is a heretical sect and it sees itself as the frontline in the fight to protect Sunni Muslims. This resistance is most evident when we take into account Persis's close links to the Dewan Dakwah Islamiyah Indonesia (Indonesian Islamic Missionary Council), commonly known as DDII. DDII established connections with Saudi Arabia and specifically the Muslim World League, Rabitat al-'Alam al-Islami, one of the vice-leaders of which was Natsir. From an international perspective, it is clear that the anti-Shi'i movement in Indonesia receives strong support from Middle Eastern countries, Saudi Arabia in particular, whilst the Shi'i movement is supported by Iran. In this context, competition and conflict between Sunnis and Shi'is in Indonesia is fuelled by competition and tension over Muslim primacy between the two big powers. The relationship between the two countries was at its lowest during the period of Khomeini's leadership, in the first decade following the establishment of the Islamic Republic of Iran. Iran successfully established an Islamic state and claims to be the sole authority and representative of 'genuine' Islam. This, along with its attempts to propagate these beliefs to the whole Muslim world, was a direct challenge to the Saudi kingdom and its hold on Muslim primacy. Iran's revolutionary message opposes the Saudi regime. [17]

\subsubsection{MUHSIN}

The assembly was initiated by two Islamic organizations, the Indonesian Mosque Council (DMI) and the Ikatan Jamaah Ahlul Bait Indonesia (IJABI). Similarly, the establishment of Muhsin in Bandung can not be separated from the initiatives of the two institutions mentioned above. Personally, Jalaludin Rahmat became an important figure in the founding of Muhsin in Bandung area. the formation of Muhsin is not to blend two ideologies or teachings of the two schools, namely: Sunni and Shi'a, but only as a place for gathering, dialogue, and social activities. "The matter of teaching each" to you your religion to me my 
religion ". Remember to establish ukhuwah Islamiyah is Allah's command in Al-Quran. [Farida] Pro-response and support for Shiites by Muhsin organizations are mostly done in the form of study activities. There are several events that have been made in between, the Festival of Islamic Culture Arts. The event is actually a form of Indonesian Culture Degree of Iran supported by the Iranian government. Muhsin himself became the executor of these activities

\subsubsection{NU}

The Nahdhatul Ulama (NU) Ahlussunah Wal Jama'ah community organization, a mindset that takes the middle path between extremist aqli (rationalist) and the extreme naqli (scripturalist). Therefore the source of thought for NU is not only the Qur'an, Sunnah, but also using the ability of reason coupled with empirical reality. Such thinking is referred to earlier thinkers, such as Abu Hasan Al-Ash'ari and Abu Mansur Al-Maturidi in theology. Then in the field of jurisprudence follow the four Hanafi Schools, Maliki, Shafi'i, and Hanbali. While in the field of Sufism, developed the method of Al-Ghazali and Junaid Al-Baghdadi, which integrate Sufism with the Shari'a bisa diakses halaman web NU. [18] NU does not agree with Shia beliefs especially to Shia in Indosesia which is part of Shia istna as'ari or Shia imamiyah.

\subsubsection{MUHAMADIYAH}

Ormas Muhammadiyah As the largest reformist Muslim organization in Indonesia, Muhammadiyah appears to take a neutral stance to Shi'ism. It does not involve itself in promoting anti-Shi'i views to its members or to Muslims at large. This is particularly true of the central board of Muhammadiyah, although there is some evidence that local branches and members do anti-Shi'i activities. Like the above-mentioned reformist associations, Muhammadiyah claims to follow the ahl al-sunna wa al-jama'a; however, its main concern, since its establishment in 1912, appears to have been with promoting the necessity of Islamic renewal in Indonesia. It is no wonder the muhammadiyah authority never conflicts with Shias. The belief about Eid al-ghadir is the same as NU.

\subsubsection{AL IRSYAD}

Zulfkifli said that Al-Irsyad, a non-Sayyid Arab organization which was founded in 1914. Its anti-Shi'i attitude appears to run parallel to its anti-Sayyid activities, carried out through Jami'at Khair, to which Ahmad Surkati was affiliated. Theological reasons also inform the anti-Shi'i attitudes of Al-Irsyad, coupled with its strong ties to anti-Shi'i groups in the Middle East. "To prohibit Shi'ism and other streams contrary to the teachings of the Qur'an and Hadith of the Prophet (May God Grant Him Peace and Salvation) in the whole de jure region of Indonesia and also all of their activities in any form, either ritual, printing or publication etc. because in the long term it is feared that these will result in the conflict of Muslims in Indonesia as adherents of the teachings of ahl al-sunna wa al-jama'ah "[19]

NU and Muhammadiyah mass organizations, being open despite disagreeing with Eid alghadir tradition, Sunni mass organizations are indeed different interpretations with ghadir khum, they believe that Ghadir khum is the command of Allah so that the Prophet is not afraid that the Quraish will kill him and admit that the event Ali has a degree and glory among other friends. It is not a command to be a caliph after the Prophet is called by Allah Swt later. As for Persis and al-Irsyat to be firm and firm against the Shiites, in addition to refusing them to demand the dissolution of the Shia community. While mass organizations muhsin more inclined and support the activities and beliefs of the Shia. Respect for the ahlu bait, there are similarities between Shiite and Sunni communities. the Sunni community is very respectful of 
Imam Ali and his descendants, but not as excessive as the Shiite community who consider Ali more noble than other companions. That Ali is as noble as the Prophet Muhammad SAW. Indeed there are some circles of the Sunni community who give excessive honors to Ali and Fatimah. Like chanting religious songs in Arabic and or regional languages. [20]

\section{Conclusion}

Afterdoingtheresearchbyconductingliteraturefromavariety ofsourcesandanalyze response the data,the authorsdraw someconclusionsaboutthe Multicultural Tradition: Islamic Mass Organization Responses To Shia's Tradition In Indonesia.

This paper has already pointed out the construction of a celebration of a strong Eid ghadir tradition within the Shi'a community. Idul ghadir is a celebration of Eid in the community of Shia in Indonesia especially Jakarta bandung. The celebration is always celebrated together. Both through the organization of Islamic societies such as IJABI, ABI and majlis taklim shia. based on interviews with some authorities of the Shia Society, every year they celebrate with pleasure. The celebration is general, meaning non-members of the community may also participate.

Coordination of celebrations is done through electronic mail and social media to their group members. If it was still not openly commemorate Eid ghadir, now has more daring to deliver the agenda to the public. Such as the manufacture and installation of Eid al-Qaeda banners, celebrations with holding public seminars in public places.

Why the Shi'a celebrate the Eid al-Ghadir tradition, from the article is very clearly mentioned the greatness of the Eid day, that Eid ul-ghadir is commemorating the great event of succession of succession of the Prophet's successor leadership after the prophet died. In addition in the tradition of Eid ghadir there is a noble value about the glory of Ali ra. and ahlu bait. In addition, Imamat is part of the faith believed by the Shia community.

From the analysis of responses in this article explains the various responses of Islamic organizations. There are many factors influencing the form of the mass organization's response. Among them is the understanding of Eid al-Ghadir. Reject because it is contrary to the conviction of the mass organization or accept because it is in accordance with the belief in the truth of Eid al-ghadir. But the most important is the difference of interpretation of the hadith and verses of the Qur'an. For Al-Irsyat and Persis mass organizations strongly reject and prohibit such activities. For Muhammadiyah and NU differed also the opinion of Eid Ghadir but did not forbid the Shiite community to celebrate. However, NU and Muhammadiyah members at the lower level may also prohibit such activities. As for Muhsin, the mass organizations agreed on the celebration whether they participated or did not celebrate.

\section{Acknowledgment}

The author would like to thank Syamsudin who has gien us information about Idul G hadir, and also would like to thank to Islamic mass organisation ANNAS 


\section{References}

[1] Hall Ian, 2014, Time of troubles': Arnold J. toynbee's twentieth century, International Affairs, 90(1) 23-36

[2] Akmal, interview, leader at Islamic Cultural Center, Jakarta.

[3] Zulkifli. (2013). 8 . Sunni Responses to Shi ' ism The Struggle of the Shi'is in Indonesia Book. ANU Press. (2013), (May 2018), 229-269.

[4] Ma'ar if research journal, Historia, No.6, 2012

[5] Afwadzi, B. (2014). Wasiat Khilāfah Pada Ali Bin Abi Thalib (Studi Komparatif Hadis Ghadīr Khum Dalam Tradisi Sunni Dan Syiah). Hermeneia: Jurnal Kajian Islam Interdisipliner, 14(1), 27-49.

[6] Zulkifli. (2013). 8 . Sunni Responses to Shi ' ism The Struggle of the Shi' is in Indonesia Book. ANU Press. (2013), (May 2018), 229-269.

[7] Surakhmad. 1998. Metode Penelitian Sosial. Bandung PT. Remadja Rosdakarya

[8] Hamad, Ibnu, (2004) Konstruksi Realiats Politikdalam media Massa, Granit, Jakarta

[9] Idul Ghadir, Wikipedia, https://id.wikipedia.org/wiki/Idul_Ghadir Accessed 15 July 2015

[10] Jabbariyan, Muhammad Ridha, Peristiwa Ghadir Dalam Perspektif Ahlusunnah

[11] Ibn Khaldun, The Muqaddimah, terjemahan, Franz Rosenthal, jilid. 1 (New York: Pantheon Books, 1958) hal. 403.

[12] The Dialectic of Power: Sunni-Shi'i Debates in Tenth-Century North Africa Author(s): Sumaiya Hamdani Source: Studia Islamica, No. 90 (2000), pp. 5-21 Published by: Maisonneuve \& Larose

[13] Jabbariyan, Muhammad Ridha, Peristiwa Ghadir Dalam Perspektif Ahlusunnah

[14] Koentjaraningrat, 1990. Manusia dan kebudayaan di Indonesia. Djambatan. Jakarta

[15] Zulkifli. (2013). 8 . Sunni Responses to Shi ' ism The Struggle of the Shi'is in Indonesia Book. ANU Press. (2013), (May 2018), 229-269.

[16] Farida, A. (2014). Islamic Mass Organizations' Responses To Shi'a Muslims In Bandung, West Java. Penamas, 27(02), 159-175.

[17] Zulkifli. (2013). 8 . Sunni Responses To Shi ' Ism The Struggle Of The Shi'Is In Indonesia Book. Anu Press. (2013), (May 2018), 229-269.

[18] [Http://Www.Nu.Or.Id/About/Sejarah] Accessed 15 July 2015

[19] Zulkifli. (2013). 8 . Sunni Responses To Shi ' Ism The Struggle Of The Shi'Is In Indonesia Book. Anu Press. (2013), (May 2018), 229-269.

[20] Siraj Said Agil, 1999, latar kultural dan politik kelahiran ahlusunah waljamaah, dalam Imam Baehaqi, kontroversi aswaja: aula perdebatan dan reinpretasi, Yogyakarta: LKiS 
